\title{
PEAK PARTICLE VELOCITY AS AN INDICATOR OF THE DYNAMIC LOAD EXERTED ON THE SUPPORT OF UNDERGROUND WORKINGS
}

\author{
Grzegorz MUTKE *, Wojciech MASNY and Stanislaw PRUSEK
}

Central Mining Institute (GIG), Plac Gwarkow 1, 40-166 Katowice, Poland

*Corresponding author's e-mail: gmutke@gig.eu

\begin{tabular}{l} 
ARTICLE INFO \\
\hline Article history: \\
Received 18 September 2015 \\
Accepted 13 June 2016 \\
Available online 29 June 2016 \\
\hline
\end{tabular}

Keywords:

Mining induced seismicity

Dynamic load on support and excavations

Peak particle velocity

\begin{abstract}
Rock mass vibrations directly affecting the roof support in roadways and load on the support were continuously measured for 78 days in the deep seismic-prone coal mine Bobrek. The mine tremor of seismic energy $\mathrm{E}=3 \mathrm{E} 5 \mathrm{~J}$ (local magnitude, $\mathrm{M}_{\mathrm{L}}=2$ ) and $\mathrm{E}=8 \mathrm{E} 3 \mathrm{~J}$ (local magnitude, $\mathrm{M}_{\mathrm{L}}=1.1$ ) located close to the tested roof support induced peak particle velocity weighted over $25 \mathrm{~Hz}, \mathrm{PPV}_{\mathrm{w}}=0.110 \mathrm{~m} / \mathrm{s}$ and $\mathrm{PPV}_{\mathrm{w}}=0.046 \mathrm{~m} / \mathrm{s}$. During the vibrations, an increase in vertical load of $82 \mathrm{kN}$ and of $100 \mathrm{kN}$ under the arch support was recorded. During vibrations induced by the other 395 seismic events, very low values of $P P V_{W}$ were recorded, i.e., less than $30 \mathrm{~mm} / \mathrm{s}$, and no significant increase in load was recorded under the arch support. However, the measurements showed that seismic events can cause a significant increase in load on the support, especially when the mine workings are located in the near seismic wave field, in which the parameters of peak particle velocity weighted over $25 \mathrm{~Hz}\left(\mathrm{PPV}_{\mathrm{W}}\right)$ reach very high values. The influence of wave motion, which is caused by a seismic event, on the steel arch support was also analyzed with FLAC software numerical modeling and showed an important increase in the calculated load on the arch steel support.
\end{abstract}

\section{INTRODUCTION}

Research into the influence of the dynamic phenomena induced by seismic events on underground workings, and their roof support, has been conducted in coal mines for over 200 years. In Polish law a rock burst phenomenon is when a mine working is destroyed or damaged, losing its functionality due to a seismic event.

The oldest description of rock bursts occurring in the Upper Silesian Coal Basin (USCB) comes from 1858 and refers to events in the Fanny mine and the Król Mine in 1875 (Bukowska, 2005).

Rock bursts are still one of the most serious natural hazards in hard coal mines in Poland. Between 2003 and 2013, in USCB, nearly 11,000 seismic events of seismic energy $E \geq 10^{5}$ (local magnitude, $M_{L} \geq 1.7$ ) of which 27 were rock bursts that resulted in material and personnel losses occurred (Stec, 2014; Patyńska, 2014). Seismic energy E is calculated using squared and integrated velocity records of radiated body waves at a short distance from a point source, and assuming a focal sphere at a distance $500 \mathrm{~m}$ from the source. The surface integral is taken over the focal sphere (Dubiński and Wierzchowska, 1973; Kanamori et al., 1993). The local magnitude is calculated using the empirical formula developed for Upper Silesia, between seismic energy and magnitude calculated from the body wave: $\log \mathrm{E}=1.8+1.9^{\cdot} \mathrm{M}_{\mathrm{L}}$ (Dubiński and Wierzchowska, 1973)

Development of seismic equipment in the $20^{\text {th }}$ century has made it possible to measure mining seismic events and assess the influence of their parameters on mine workings and their roof support units. The measurements can be divided into three main categories:

- measurement-of ground motion in underground workings in deep mines, especially in the near field (Butler and van Aswegen, 1993; McGarr et al., 1991; Dubiński and Mutke, 1996; Kaiser et al., 2005; Mutke, 2002, 2008)

- measurement of load on the support during natural dynamic phenomena (Szweda, 2003; Masny and Prusek, 2012; Jarufe and Vasquez, 2014; Kaiser and Cai, 2013)

- measurement of PPV and of load on the roof support during blast experiments (Kidybiński, 1986; Tannant et al., 1992; Stjern and Myrvang, 1998; Hagan et al., 2001; Ansell, 2004; Malmgren and Nordlund, 2006; Masny, 2006; Hadjigeorgiou and Potvin, 2008; Heal, 2010)

The most important conclusions of these articles in terms of our study are as follow. Butler and van Aswegen (1993) presented some data, for the gold mines in South Africa, indicating that the peak particle velocity (PPV) in the near field can exceed the value of $10 \mathrm{~m} / \mathrm{s}$ (probably related to the ejection velocity of rock). Case studies from Dubiński and Mutke (1996) show recorded PPV $=0.03 \mathrm{~m} / \mathrm{s}$ at the dominant frequency of $5-20 \mathrm{~Hz}$ and a peak particle acceleration (PPA) of over $5 \mathrm{~m} / \mathrm{s}^{2}$. The highest value of PPV recorded from a mining induced seismic event in the USCB in the coal seam reached $\mathrm{PPV}=$ $0.380 \mathrm{~m} / \mathrm{s}$ and PPA $=40 \mathrm{~m} / \mathrm{s}^{2}$ (seismic energy $\mathrm{E}=$ 
8E3 J, local magnitude $\mathrm{M}_{\mathrm{L}}=1.1$ at distance $\mathrm{d}=110 \mathrm{~m}$ and frequency range $f<100 \mathrm{~Hz}$ ) (Mutke, 2002). The empirical equation between the parameters PPV $\mathrm{R}$ and $\mathrm{M}_{\mathrm{o}}$ are presented by McGarr et al. (1981) for gold mines in South Africa:

$\log (P P V \cdot R)=0.49 \cdot \log \left(M_{0}\right)-4.68$

where: $(P P V \cdot R)$ - is in $\mathrm{cm}^{2} / \mathrm{s} ; R$ is hypocentral distance in $\mathrm{cm}, \mathrm{M}_{0}$ is in dyn $+\mathrm{cm}$.

For a set of 65 seismic events, for which PPV values were measured in near field, a similar empirical equation was determined by Mutke $(2007,2008)$ for coal mines in Upper Silesia, Poland:

$\log (P P V w \cdot R)=0.66 \cdot \log \left(M_{0}\right)-7.4$

where: $(P P V w \cdot R)$ - is in $\mathrm{m}^{2} / \mathrm{s} ; R$ is hypocentral distance in $\mathrm{m}, M_{0}$ is in $\mathrm{N} \cdot \mathrm{m}$

Kaiser and Cai (2013) proved PPV and the resulting dynamic loading impact on excavations, play an important and dominant role in the damaging effect for excavations very close to a large fault-slip seismic event. In other cases, such as the strain-burst mechanism, the additional dynamic load is only one of a few factors that influence the strain-burst phenomena. From their experience, the relationship between ground motion and yielding support is too simplistic or even incorrect.

Important tests with the use of explosives to induce rock mass vibrations were conducted by Hadjigeorgiou and Potvin (2008), Heal (2010), Reddy and Spottiswoode (2001) and Hagan et al. (2001). As a result of these tests, two areas of damage were observed: one on a sidewall in the direct vicinity of the explosive charges (where the damage was serious) and the other one in the remaining part of the working (where the damage was light). Apart from loose rocks that fell from the roof, no other damage was observed in the remaining part of the working i.e., the roof, the floor, and the sidewall opposite the blast experiment. The sensors recorded a value of PPV of $3.3 \mathrm{~m} / \mathrm{s}$ in the area of serious damage (the probe was ejected together with a rock boulder) and $1.6 \mathrm{~m} / \mathrm{s}$ in the area of light damage-

Szweda (2003) presented the results of dynamic load measurements performed using tensometers placed on a mechanical lengthener of a hydraulic leg of a section of a powered roof support. The most important conclusion of the research by Szweda is that the dynamic load of a section of a powered roof support in the case of a seismic event induced by mining is significantly higher than the dynamic load induced by explosives.

The behavior of bolts during tremors simulated by explosives was a subject of studies conducted underground in the Lac Shortt mine, northern Quebec, Canada (Tannant et al., 1992). During the tests, the values of PPV from 1.0 to $3.8 \mathrm{~mm} / \mathrm{s}$ were recorded, and it was concluded that, in general, the seismic events caused very little dynamic stress compared to the value characteristic for steel $(380$ to $520 \mathrm{MPa})$. The results of the measurements of the load induced by a seismic event on a support were also presented in the paper of (Masny and Prusek, 2012). The following article presents the measurements of the load on a roof support in one of the USCB coal mines during seismic events. The load on the support was measured together with ground motion. Based on the results of the measurements, possible additional analyses applying numerical modeling are presented.

\section{METHODOLOGY}

Seismic events induced by mining are the source of dynamic load on mine workings. Sufficiently large dynamic load can damage or even destroy a mine working, as well as cause dynamic displacement of the miners. Linear objects (roadways and mine shafts) located in the rock mass are subjected to similar deformations as the surrounding rocks. The basic types of dynamic influence on roadways and shafts are axial strain, bending strain and circumferential strain.

\subsection{BACKGROUND}

Empirical research conducted in numerous underground test sites shows that high values of amplitude (displacement, velocity and acceleration) are recorded only for the near field (McGarr, 1981; Dubiński and Mutke, 1996; Mutke, 2008). In the near seismic field, the amplitudes of the waves are subjected to strong damping, and in the far field, only low values of vibrations are recorded (Fig. 1).

Research into the destructive effects of vibrations in the workings (rock bursts) caused by mine seismic events in the USCB showed that only events located close to the mine workings resulted in damaging effects (Mutke, 2007). In the near field, we

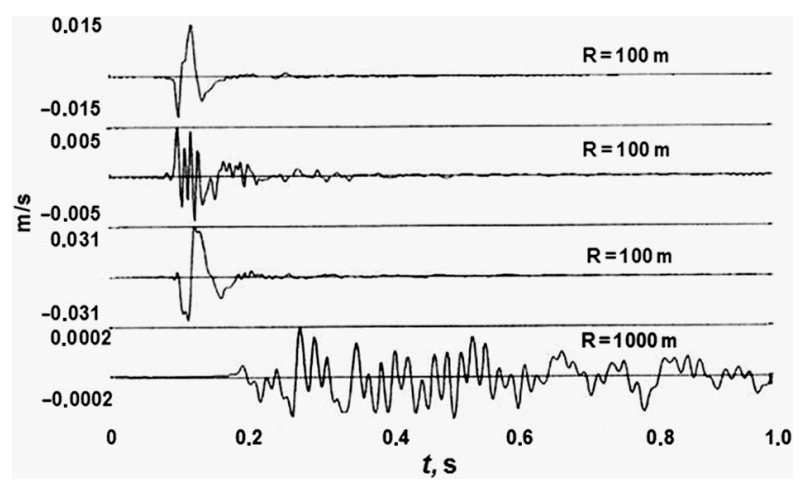

Fig. 1 Ground motion velocity of a mine seismic event recorded with three axial geophones in the near field $(\mathrm{R}=100 \mathrm{~m})$ and the vertical component recorded in the far field $(\mathrm{R}=$ $1000 \mathrm{~m}$ ) in the Slask mine. 
usually consider a directed wave impulse of vibrations (Fig. 1). Depending on the seismic event mechanism (implosive, shear) and the orientation of a seismic event source towards a mine working, we observe P-wave longitudinal strain, normal tensile and compressive strain, and S-wave shear strain in a working. The maximum P-wave longitudinal and normal strain is defined as follows (Dowding, 1985):

$\varepsilon_{1 \mathrm{~m}}=+\Delta P P V_{P} / c_{p} \quad$ for angle $\Phi=0^{\circ}$

$\varepsilon_{1 \mathrm{n}}=+\Delta P P V_{P} / c_{p} \quad$ for angle $\Phi=90^{\circ}$

where:

$c_{p}$ - propagation velocity of the $\mathrm{P}$-wave, $\mathrm{m} / \mathrm{s}$,

$\mathrm{PPV}_{\mathrm{P}}$ - amplitude of the peak particle velocity (longitudinal wave), $\mathrm{m} / \mathrm{s}$.

Where as the S-wave maximum shear strain $\gamma_{\mathrm{m}}$, is:

$\gamma_{\mathrm{s}}=\Delta P P V_{S} / c_{s} \quad$ for angle $\Phi=0^{\circ}$

where:

$\mathrm{c}_{\mathrm{s}}-\mathrm{S}$-wave propagation velocity, $\mathrm{m} / \mathrm{s}$,

$\triangle \mathrm{PPV}_{\mathrm{S}}$ - maximum amplitude of the peak particle velocity (transverse wave) $\mathrm{m} / \mathrm{s}$.

The calculated values of deformation are applied to determine the dynamic stress. The P-wave maximum longitudinal stress $\sigma_{\mathrm{m}}$ and the normal stress $\sigma_{\mathrm{n}}$ towards the axis of a working are (Dowding, 1985):

$$
\begin{array}{ll}
\sigma_{m}=\frac{(1-v) E}{(1+v)(1-2 v)} \frac{P P V_{p}}{c_{p}}, & \varphi=0 \\
\sigma_{n}=\frac{(1-v) E}{(1+v)(1-2 v)} \frac{P P V_{p}}{c_{p}}, & \varphi=90^{\circ}
\end{array}
$$

The S-wave maximum shear stress is:

$$
\sigma_{s}=\frac{G v_{s}}{c_{s}}=\rho \cdot P P V_{s} \cdot c_{s}, \quad \varphi=0
$$

where:

$$
\begin{aligned}
& \mathrm{G} \text { - stiffness modulus, } \mathrm{Pa} \\
& \rho \text { - density, } \mathrm{kg} / \mathrm{m}^{3} \\
& \text { E - Young's modulus, } \mathrm{Pa} \\
& v \text { - Poisson's ratio, dimensionless. }
\end{aligned}
$$

Once the course of vibrations is recorded in the place where their potential consequences will be assessed, it is possible, knowing the amplitude of PPV, to determine the strain and the dynamic stress, e.g., for $\mathrm{PPV}=0.05 \mathrm{~m} / \mathrm{s}$, the $\mathrm{S}$-wave dynamic stress can be $\sigma_{\mathrm{S}}=0.33 \mathrm{MPa}$, and for $\mathrm{PPV}=1 \mathrm{~m} / \mathrm{s}$, the dynamic pressure can be $\sigma_{\mathrm{S}}=6.5 \mathrm{MPa}$ for typical values of $\mathrm{G}, \rho, \mathrm{E}$ and $v$ in USCB. The strain is primarily responsible for the formation of cracks (rock mass is susceptible to tensile forces). Underground measurements performed using special seismic probes enable direct read out of the value of PPV. The value of PPV is a very important parameter, which is directly dependent on the strain and stress and which is proportional to the seismic energy of a seismic event and its magnitude (Dowding, 1985). Parameter PPV is widely applied as an indicator in assessing the influence of the vibrations on the underground infrastructure. Hence, the measurement is crucial in assessing rock burst hazard in underground workings.

\subsection{METHOD OF ASSESSING SEISMIC HAZARDS ON UNDERGROUND WORKINGS IN POLISH COAL MINES}

In the method of assessing the hazard to the stability of underground workings subjected to the influence of seismic events, parameter PPV is continuously monitored. To perform this assessment, two or more sparkproof portable uniaxial and 3-axial borehole geophones model DLM-PPV, recording the velocity up to amplitude of $1.0 \mathrm{~m} / \mathrm{s}$, are connected to the seismic network. The DLM-PPV velocity probes were mounted in roadways, no farther than $200 \mathrm{~m}$ from the longwall front. Afterwards, their location should follow the longwall front advance. With boreholes geophones located as described above, it is possible to constantly monitor changes in the values of PPV.

To obtain comparable and significant values of PPV, due to the possible effects of vibrations in an excavation, a weight function considering the frequency of the seismic events is applied. The recorded values of PPV amplitude are rectified with the weight function in two ranges:

- for lower frequencies $f €\left(0, f_{M}\right)$, the weight is equal to 1.0 ,

- for higher frequencies $f>f_{M}$, the weights are lower than 1.0.

The weights are selected based on an analysis of the corner frequencies calculated for seismic events with the effect of rock bursts in USCB mines. The corner frequencies are the frequencies that carry most of the seismic energy and momentum. The weight enables elimination of high values of parameter PPV, which are irrelevant for the unfavorable reaction of a mine working to dynamic load. Numerous criteria found in the literature indicate the PPV resulting in destruction of the excavations disregard the frequency characteristics of the vibrations. E.g., PPV vibrations after blast works are very high in the near seismic wave field, but they have very high frequencies and they do not damage mine workings, even when the value of $1.0 \mathrm{~m} / \mathrm{s}$ is exceeded (Hagan et al., 2001). The characteristics of the vibrations of numerous weak seismic events recorded at the panel face line of a longwall system of mining less than $10^{4} \mathrm{~J}$ (or less than 1.2 of local magnitude) appear to be very similar and do not pose a danger for excavations. In other words, high frequency seismic waves are less dangerous than lower frequency ones. 
Calculations of seismic source parameters of 26 rock bursts (seismic events which caused significant failure in excavations) that occurred in Upper Silesian mines in the period 1998-2006 (Mutke, 2007) formed a basis for the development of weight function. The rock bursts caused destruction of the mine workings after every phenomenon in length from $22 \mathrm{~m}$ to $290 \mathrm{~m}$. The seismic moments were for those rock bursts from $3.5 \mathrm{E} 11$ to $3.0 \mathrm{E} 14 \mathrm{Nm}$, the seismic energies from $3 \mathrm{E} 5 \mathrm{~J}$ to $2 \mathrm{E} 8 \mathrm{~J}$, and the stress drops from $0.15 \mathrm{MPa}$ to $25 \mathrm{MPa}$. The corner frequencies varied from $8.3 \mathrm{~Hz}$ to $31.1 \mathrm{~Hz}$. For the $85 \%$ of rock bursts, the corner frequency does not exceed $23 \mathrm{~Hz}$. The relationship between corner frequencies and scalar seismic moments for rock bursts phenomena in USCB is presented in Figure $2 \mathrm{a}$ and the relationship between corner frequencies and seismic events in Figure 2b. Given the empirical results of the study we assumed, that rock burst hazard is linked with seismic events characterized by low corner frequency, generally less than $25 \mathrm{~Hz}$. In addition, the energy of rock bursts that occurred in the Upper Silesian Coal Basin generally exceeded seismic energy of 1E5 J (Fig. 2b). The studies allowed establish a weight function with the characteristics shown in Figure 2c.

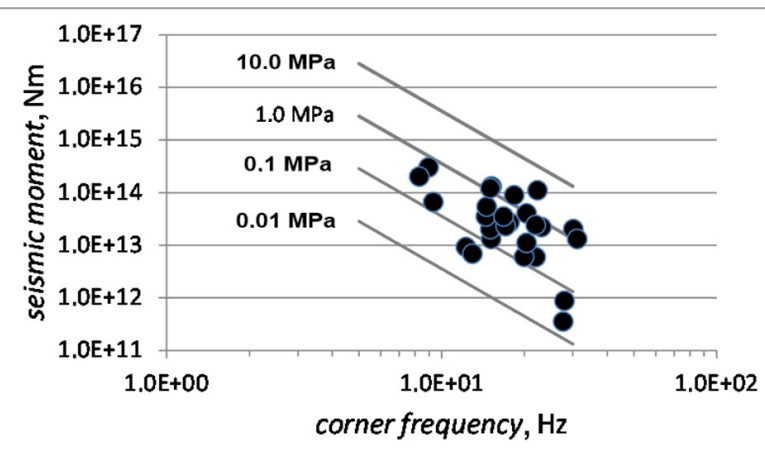

Fig. 2a The relationship between corner frequencies and scalar seismic moments for rock bursts in USCB recorded in the 1998-2006 years.

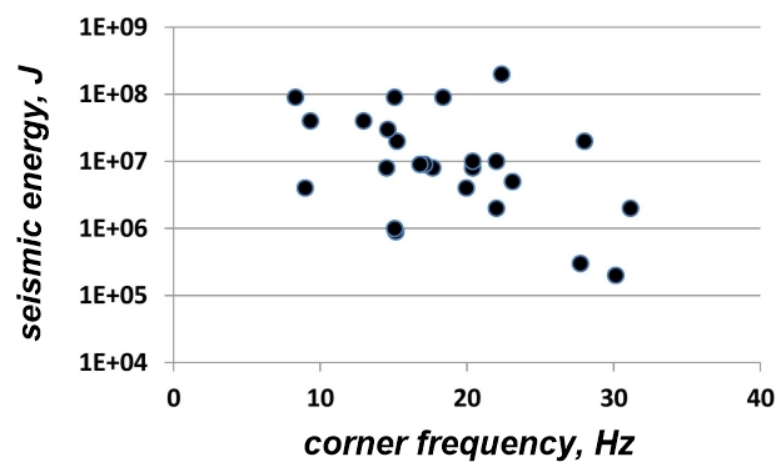

Fig. 2b The relationship between corner frequencies and seismic energies for rock bursts (seismic events which caused significant failure in tunnels) in USCB recorded in the 1998-2006 years.

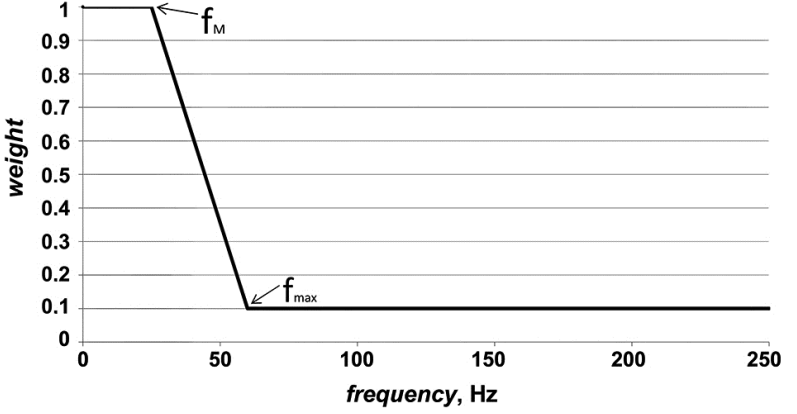

Fig. 2c Example of the shape of the weight function applied to rectify the recorded values of PPV.

\subsection{CRITERIA OF ASSESSING THE ROCK BURST HAZARD IN WORKING OPENINGS}

The statistics of rock bursts in the USCB coal mines shows that the sources of mine seismic events leading to destruction of a mine excavations were usually located no farther than 300 meters away. Measurements and empirical research conducted in the USCB enabled the development of an empirical scale to assess the influence of vibrations on the stability of mine workings. To do so, 120 rock bursts that occurred in USCB coal mines were analyzed, and then the observed effects were correlated with the parameter PPV, weighted in the range of frequency of the most dangerous vibrations $\left(\mathrm{PPV}_{\mathrm{w}}\right)$. The criterion shows that damage to the USCB mine excavations occurred in individual cases at PPV's as low as $0.05 \mathrm{~m} / \mathrm{s}$. The vast majority i.e., $90 \%$, of the analyzed rock bursts that occurred in 1988-2006 in the USCB, fell within the range of $\mathrm{PPV}_{\mathrm{w}}$ between 0.05 and $1.0 \mathrm{~m} / \mathrm{s}$ (Mutke, 2007 and 2008).

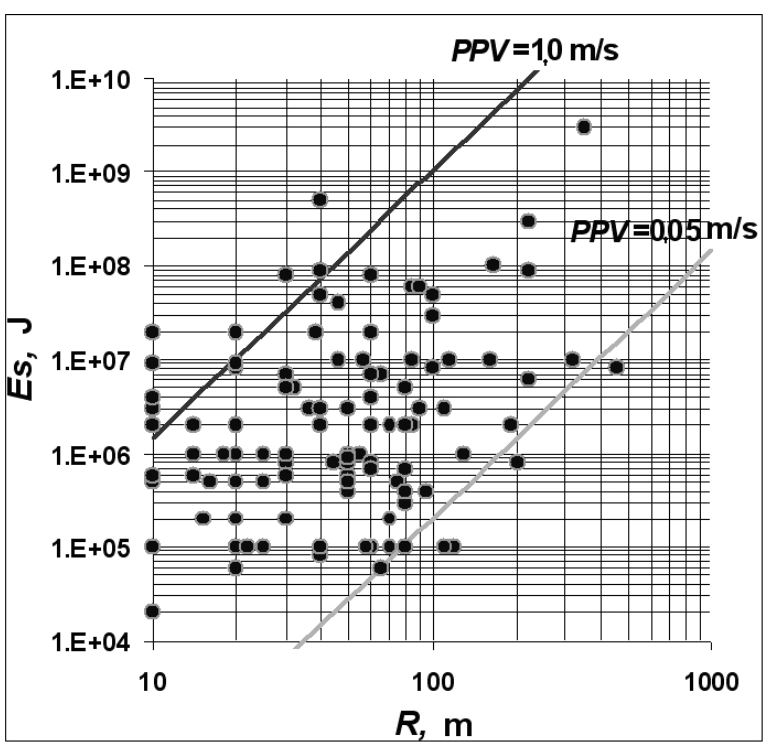

Fig. 3 Diagram presenting 120 rock bursts in USCB, 1988-2006: distance from damaged working $R$ - seismic energy $\mathrm{E}_{\mathrm{s}}$; lines of constant $\mathrm{PPV}_{\mathrm{W}}$ values $(0.05$ and $1.0 \mathrm{~m} / \mathrm{s})$ are marked in the graph (after Mutke, 2007). 


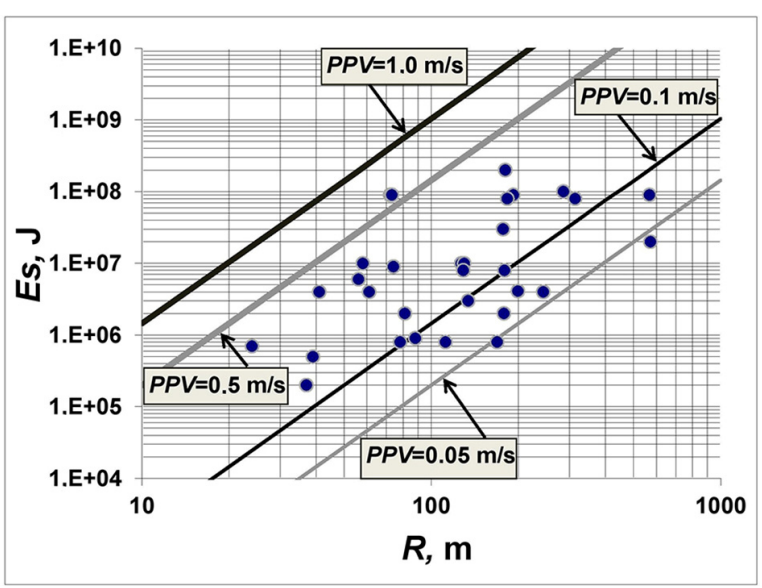

Fig. 4 Diagram presenting 32 rock bursts in Polish Coal Company mines during the period 2003-2012; R - distance from the damaged working, $E_{S}$ - seismic energy; lines of constant $\mathrm{PPV}_{\mathrm{W}}$ amplitudes $(0.05,0.1,0.5$ and $1.0 \mathrm{~m} / \mathrm{s}$ ) are marked in the graph.

Similar results were obtained for rock bursts in Polish Coal Company mines (Fig. 4), i.e., $\mathrm{PPV}_{\mathrm{W}}$ is an important element of the influence of vibrations on the stability of the excavations and the support conditions.

The values of $P P V_{W}$, for given levels of the potential hazard to the stability of a working are as follows (Dubiński and Mutke, 2012):

(a) - no risk: $P P V_{W} \leq 0.05 \mathrm{~m} / \mathrm{s}$,

(b) - low risk: $0.05<\mathrm{PPV}_{\mathrm{W}} \leq 0.2 \mathrm{~m} / \mathrm{s}$,

(c) - average risk: $0.2<\mathrm{PPV}_{\mathrm{W}} \leq 0.4 \mathrm{~m} / \mathrm{s}$,

(d) - high risk: $P P V_{W}>0.4 \mathrm{~m} / \mathrm{s}$.

Note that when mining activities are conducted in areas of concentrated stress, damage to the workings and supports can occur at lower values of $\mathrm{PPV}_{\mathrm{W}}$.

\section{THE FIELD MONITORING SITE AT THE BOBREK MINE}

To verify the elaborated criteria of empirical assessment of stability of mine workings under dynamic load induced by seismic events, measurements were performed in coal mine Bobrek located in USCB.

Three uniaxial borehole geophones DLM-PPV and one triaxial borehole geophone DLM-PPV3D were fixed in the roadways of a longwall panel, located in the floor layer of up to 9.5 meter-thick coal seam. The mining height did not exceed $2.4 \mathrm{~m}$, and the width of the longwall varied between approximately $40.0 \mathrm{~m}$ and $140.0 \mathrm{~m}$. The coal seam was deposited at a depth between $575.0 \mathrm{~m}$ and $715.0 \mathrm{~m}$ below the surface. The location of the borehole sensors are presented in Figure 5. Tri-axial borehole geophones $23 \mathrm{Z}$, were placed in the gate road approximately $70.0 \mathrm{~m}$ below the analyzed longwall panel.

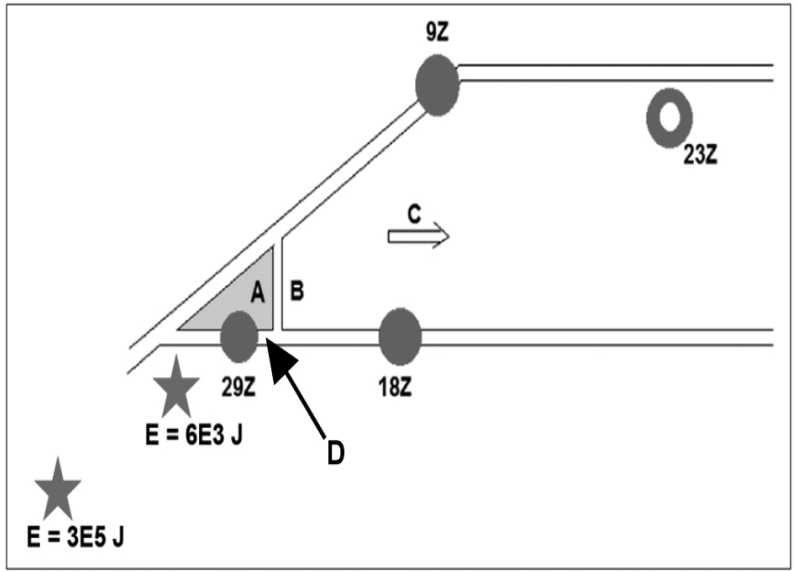

Fig. 5 Locations of the measuring borehole geophones and the epicenter of two chosen seismic events in the area of field study (A - coal seam remnant, $\mathrm{B}$ - opening cross cut of longwall, $\mathrm{C}$ mining direction, $\mathrm{D}$ - equipment location to measure the load on arch support and rockbolts).

Interpretation of the recorded seismic events included the following tasks: location, calculating their seismic energy, determining the values of $P P V_{w}$ in the given measuring stations, and calculating the distance between a seismic event and the given measuring stations. The frequency weight function had the following shape (Fig. 2b):

- for lower frequencies $f €\left(0, f_{M}\right)$, the weight equals $1.0, \mathrm{f}_{\mathrm{M}}=25.0 \mathrm{~Hz}$

- for higher frequencies $f>f_{M}$, the weights are lower than 1.0, and the weight function exhibits a linear decrease from 1 for $f_{M}=25.0 \mathrm{~Hz}$ to 0.1 for $\mathrm{f}_{\max }=60.0 \mathrm{~Hz}$.

The weight function rectified the maximum values of PPV, reducing the amplitudes of PPV of high frequencies (e.g., blast works or falling of small pieces of rock mass in overstressed areas recorded from a short distance) that are irrelevant for a roadway stability assessment.

Apart from the described measurements and analyses of parameters concerning seismic events equipment conducting measurements of the vertical load exerted on the steel arch roof support and rock bolts was mounted. The vertical load was monitored during 78 days of the test field study. The diagram of the measuring system in the mine working is presented in Figure 6.

As shown in Figure 6, hydraulic dynamometers, both under the feet of an arch support and on the rock bolts e.g., flexible ones, are connected with pressure transmitters. In addition, for controlling purposes, a manometer is located with each of the dynamometers. The measurement signals from the pressure transmitters are collected by a device for data acquisition and transmission, and are then sent to the surface with the telecom and IT network to be finally recorded on a PC with special software installed. 


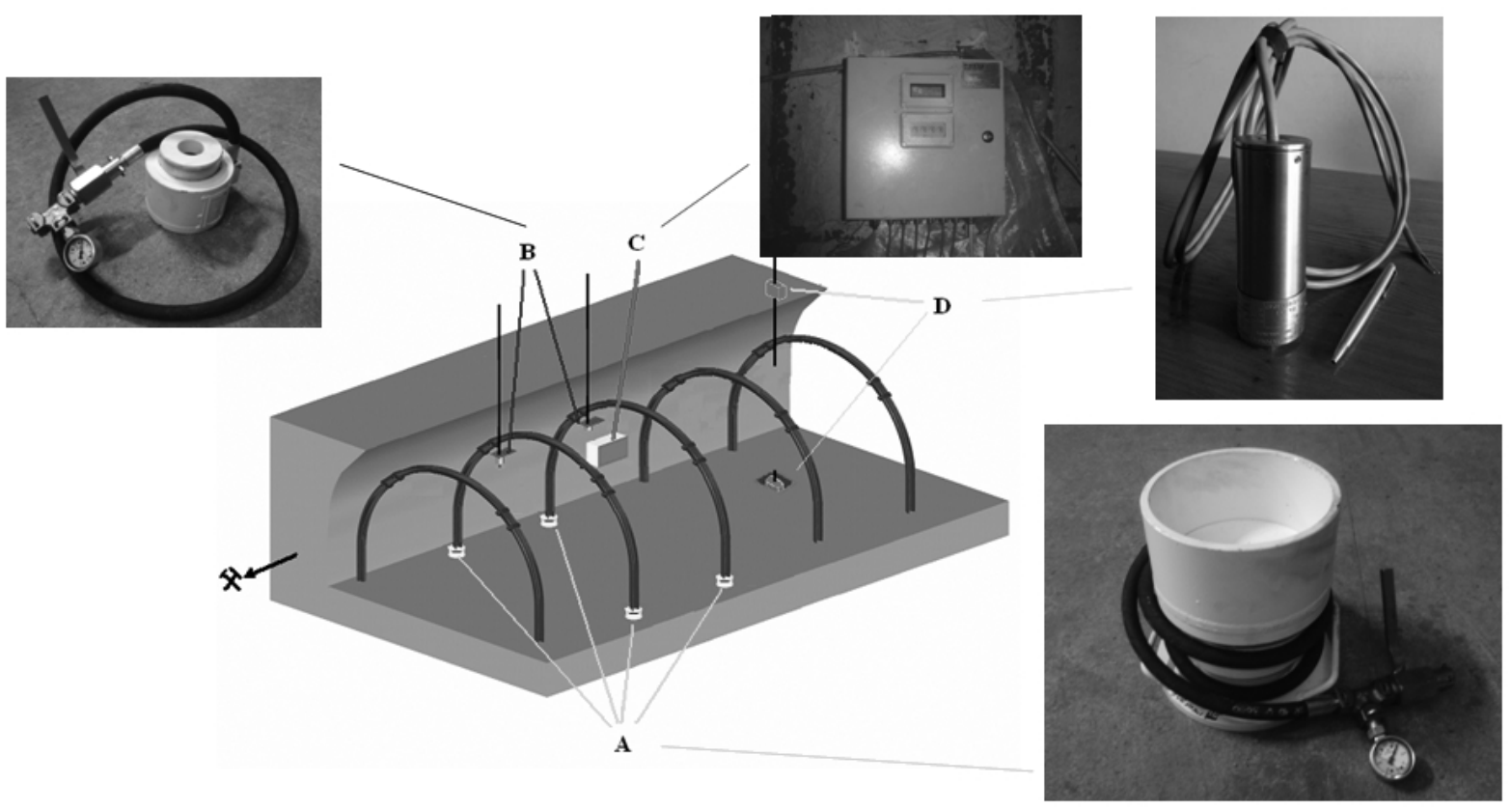

Fig. 6 Diagram of the measurement area: A - dynamometers under steel arches, B - dynamometers on bolts, $\mathrm{C}$ - device for data acquisition and transmission, and D - borehole geophone.

a)

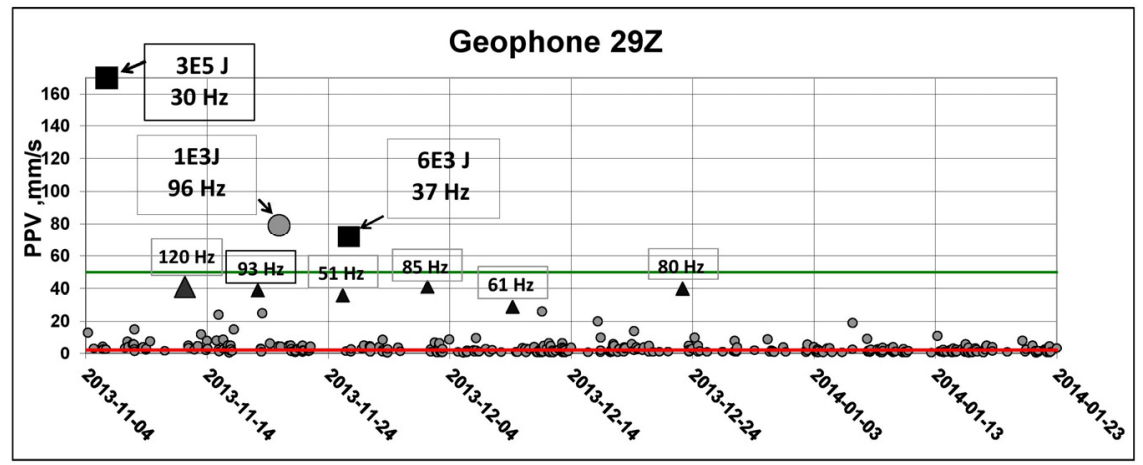

b)

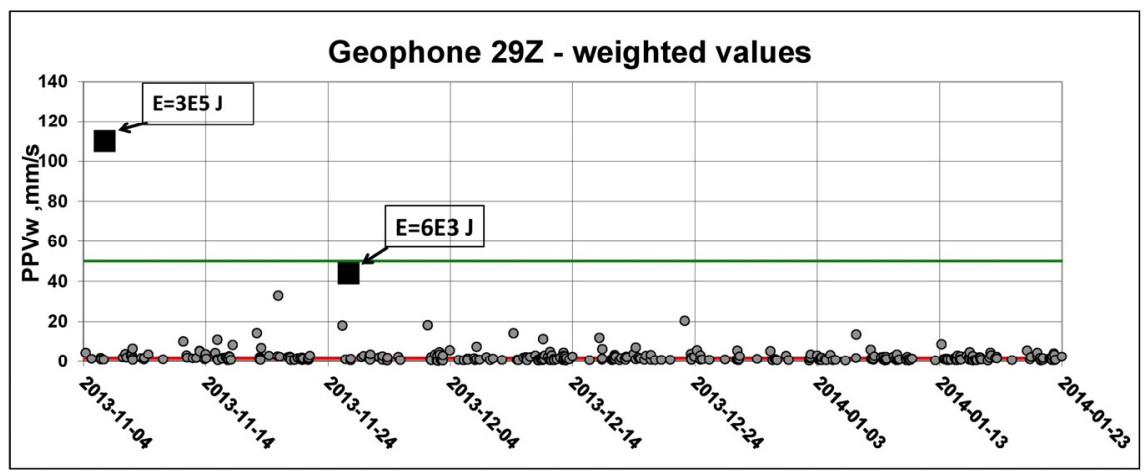

Fig. 7 Raw values of the PPV parameters recorded on the geophone No. 29Z (a). Recorded and weighted values of the PPV $\mathrm{W}_{\mathrm{W}}$ parameter for geophone No. 29Z -78 days of observation (b). (For highest PPV events the frequencies of main phase vibrations are marked. Triangles mean vibration induced by explosives; big triangle means explosive vibrations shown as an example in Figure 8; squares mean vibration induced by mining and that result in the highest load increase on support; big grey circle means low energy seismic event characterized by high PPV but only in range of high frequency vibration; small grey circle means seismic events characterized by low PPV - lower than $40 \mathrm{~mm} / \mathrm{s}$ ). 
Table 1 Results of the measured load on the support and seismic event parameters.

\begin{tabular}{|c|c|c|c|c|c|c|c|c|c|c|}
\hline \multirow{3}{*}{$\begin{array}{l}\text { Date, } \\
\text { time }\end{array}$} & \multicolumn{6}{|c|}{$\begin{array}{l}\text { Increase in load on steel roof support and rock bolts } \\
\qquad[\mathrm{kN}]\end{array}$} & \multirow{3}{*}{$\begin{array}{c}\text { Seismic } \\
\text { energy of } \\
\text { seismic event } \\
{[\mathrm{J}]}\end{array}$} & \multirow{3}{*}{$\begin{array}{l}\text { Distance between } \\
\text { the hypocenter of } \\
\text { seismic event and } \\
\text { the geophone No. } \\
29 \mathrm{Z}[\mathrm{m}]\end{array}$} & \multirow{3}{*}{$\begin{array}{c}\text { Dominant } \\
\text { frequency of } \\
\text { vibrations } \\
{[\mathrm{Hz}]}\end{array}$} & \multirow{3}{*}{$\begin{array}{l}\mathrm{PPV}_{\mathrm{W}}, \\
{[\mathrm{m} / \mathrm{s}]}\end{array}$} \\
\hline & \multicolumn{4}{|c|}{$\begin{array}{l}\text { Dynamometers under steel roof } \\
\text { support }\end{array}$} & \multicolumn{2}{|c|}{$\begin{array}{c}\text { Dynamometers } \\
\text { on rock bolts }\end{array}$} & & & & \\
\hline & D1 & D2 & D3 & D4 & D5 & D6 & & & & \\
\hline 17:38:39 & 1.1 & 28 & 2.5 & 82 & 1.9 & 1.9 & $3 \mathrm{E} 5$ & 132 & 30 & 0.110 \\
\hline $\begin{array}{c}2013.11 .25 \\
16: 16: 43\end{array}$ & 5 & 0 & 14 & 100 & 0 & 0 & $6 \mathrm{E} 3$ & 60 & 35 & 0.046 \\
\hline
\end{tabular}
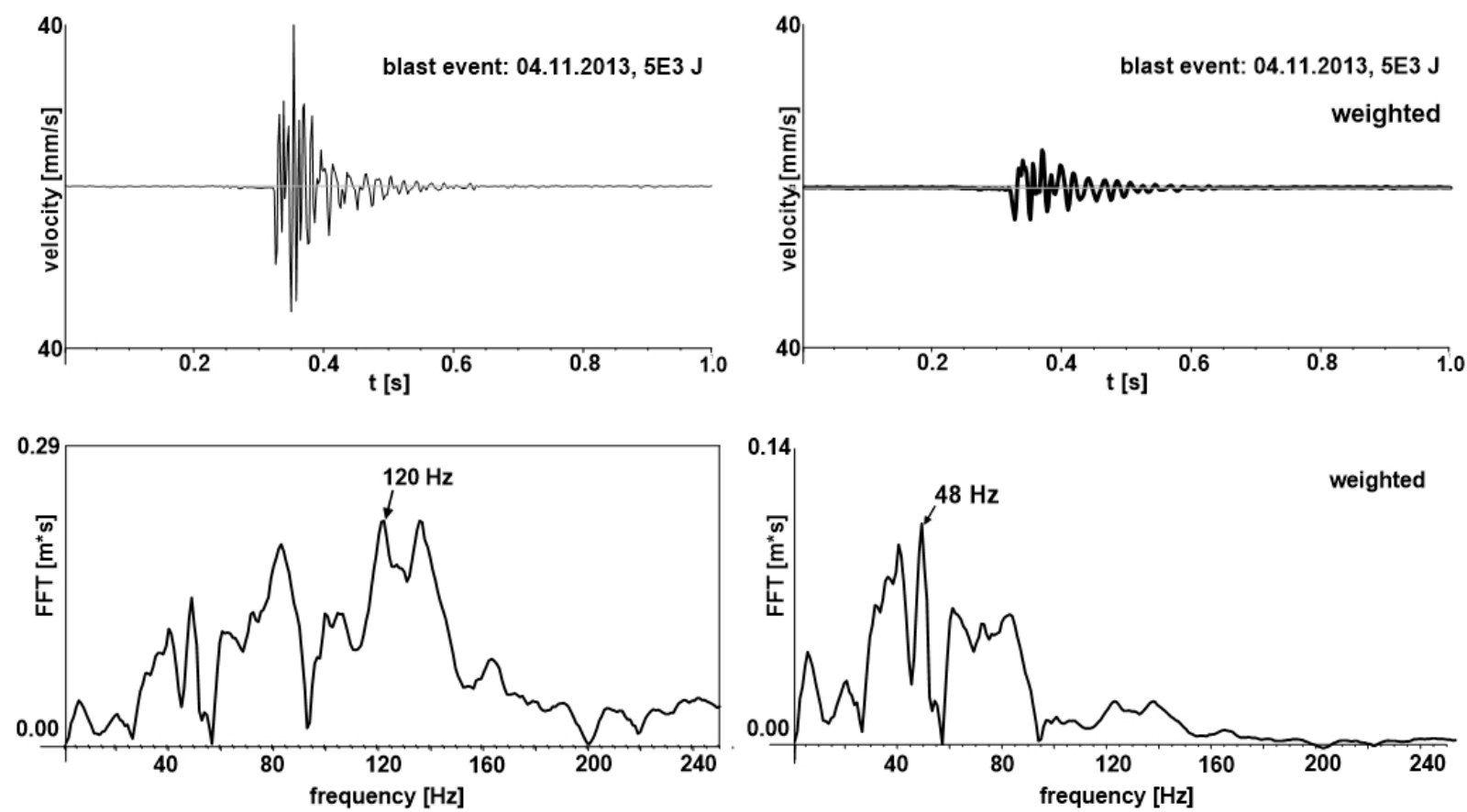

Fig. 8 Raw vibrations of the seismic event of 4 November 2013 and seismic energy $E=5 \cdot 10^{3} \mathrm{~J}$ (top-left), weighted seismogram (top right) and FFT calculated for the raw seismogram (bottom left), FFT calculated for the weighted seismogram (bottom right).

\section{RESULTS OF MEASUREMENTS}

Figure 7a presents raw recorded values of PPV on geophone probe $29 \mathrm{Z}$ fixed in rock mass near the tested arch support and Figure $7 \mathrm{~b}$ the results of the recorded and weighted values of $\mathrm{PPV}_{\mathrm{W}}$. We observe that for raw records there are in a few cases the PPV exceeding $40 \mathrm{~mm} / \mathrm{s}$ linked to high frequencies above $25 \mathrm{~Hz}$, but we don't observe load increase in arch support for these events in Figure 9. Significant load increases in arch support were measured only in two cases, where the PPV exceeded $40 \mathrm{~mm} / \mathrm{s}$ and were characterized by low frequency vibrations after weighting (Fig. 7b and Table 1). None of the 395 seismic events recorded within 78 days at the field site did correspond to rock burst (seismic phenomenon which caused significant failure in excavations).

Unprocessed and weighted seismograms of explosive vibrations are shown in Figure 8. This is an example of the seismic event with high corner frequency, $\mathrm{f}_{\mathrm{o}}=48 \mathrm{~Hz}$ and the relatively high value of raw PPV recorded at the field site $(42 \mathrm{~mm} / \mathrm{s})$. For this vibration load has not been registered in the arch support. After weighted of raw vibrations the $\mathrm{PPV}_{\mathrm{w}}$ results $9 \mathrm{~mm} / \mathrm{s}$ only. When we compare this value with the entire set of weighted vibrations shown in Figure $7 \mathrm{~b}$, we can see that this seismic event is among the phenomena of low values of $\mathrm{PPV}_{\mathrm{w}}$, for that additional load on arch support and rock bolts has not been registered. It is example how weighting changed the raw records and the structure of the spectrum and why after this type of seismic events the load increase on the support is not observed.

Figure 9 shows the results of measurements of load on an arch support and rock bolts conducted for 78 days.

Having compared the measured load and tremor parameters, two tremors were selected that undoubtedly resulted in an increase in load on the roof 

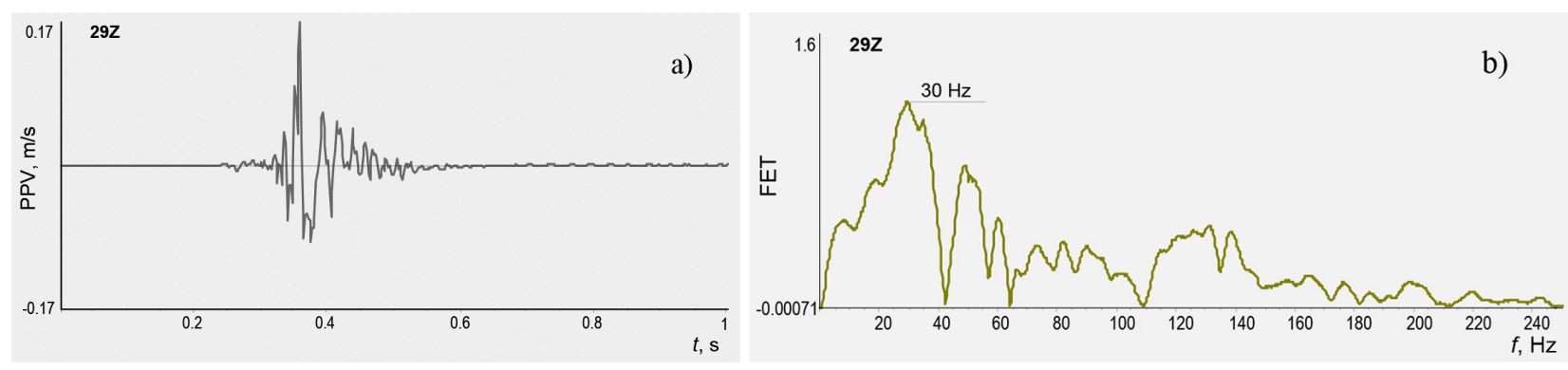

Fig. 10 Seismogram of the seismic events of 5 November 2013 and seismic energy E=3.10 $0^{5}$ (a) and FFT calculated for the seismogram (b).

support. As we can see, only these two seismic events have $P P V_{W}$ values that exceed $45 \mathrm{~mm} / \mathrm{s}$. Other seismic events induced very small values of $P P V_{W}$ in the area of the studied support (Fig. 7b). They are marked A and B in Figure 9. Data concerning the two phenomena are presented in Table 1.

Figure 10 presents a recorded mining seismic event on 5 November 2013 with seismic energy $\mathrm{E}=3 \mathrm{E} 5 \mathrm{~J}$ and its frequency interpretation. The value of PPV before weighting was $0.17 \mathrm{~m} / \mathrm{s}$, and after weighting the $\mathrm{PPV}_{\mathrm{W}} 0.110 \mathrm{~m} / \mathrm{s}$. For the analyzed tremor, the frequency of the dominant vibrations recorded by geophone No. 29 was $30 \mathrm{~Hz}$. The miners reported that the mining seismic event of energy $\mathrm{E}=3 \mathrm{E} 5 \mathrm{~J}$ induced very strong vibrations and introduced fear into the miners.

\section{NUMERICAL ANALYSIS OF DYNAMIC LOAD ON STEEL ARCH SUPPORT IN MINE}

Applying data on geological and mining conditions in the area of measurements and the record of the tremor on 5 November 2013 after weighting, numerical calculations were conducted using FLAC software. The calculations were aimed at demonstrating that it is possible to use numerical modeling to assess the behavior of a roof support under the influence of dynamic phenomena. The program FLAC, which is most often used for analyses of mining events, is designed to solve geotechnical engineering or soil mechanics problems. It simulates structures consisting of rocks, steel and other materials. Together with an optional 'dynamic' package, the program become capable of analyzing issues associated with dynamics. From the stability point of view, the maximum load on a support, both during and after a dynamic phenomenon, was important. Reduced stress in the arch support profile indicated stability of the support according to distortion energy theory, developed by Huber, von Mises and Hencky (also known as: HMH stress). Reduced stress (HMH stress) is expressed as the following equation:

$$
\sigma_{\text {red }}=\sqrt{\left(\frac{M_{g}}{W_{x}}+\frac{N}{A}\right)^{2}+3 \cdot\left(\frac{T}{A}\right)^{2}}
$$

where:

$$
\begin{aligned}
& M_{g} \text { - bending moment, } \mathrm{Nm}, \\
& N-\text { axial force, } \mathrm{N}, \\
& T-\text { shearing force, } \mathrm{N}, \\
& W_{x}-\text { section modulus, } \mathrm{m}^{3}, \\
& A-\text { cross section area, } \mathrm{m}^{2}
\end{aligned}
$$

Reduced stress $\sigma_{\text {red }}$ cannot exceed the values of permissible stress $\sigma_{\text {dop }}$, which, for a $\mathrm{V}$ profile and size 29 (type V29), are: $623.22 \mathrm{MPa}$ (steel of mechanical properties according to Polish Standard PN-H-93441$1: 2004$ ) or $708.31 \mathrm{MPa}$ (steel of higher mechanical properties according to Polish Standard PN-H84042:2009). An arch roof support was modeled in a $5.0 \mathrm{~m} \times 3.5 \mathrm{~m}$ (width $\times$ height) mine working. The parameters of the profile cross-section were assumed based on the data provided by the manufacturer.

The assumed strength and strain parameters of the rock mass for the conditions in the analyzed mine are in Table 2.

Figure 11 presents the numerical model together with the analyzed mine working.

Moreover, the following assumptions were made in numerical calculations:

- the rock mass was modeled as a plate in plane strain state, consisting of 10,000 elements and divided with computational grid into $0.5 \mathrm{~m}$ $\times 0.5 \mathrm{~m}$ cells.

- along side edges displacement conditions were assumed for static calculations; on both side edges, null horizontal displacement was assumed, and on the bottom edge, null vertical displacement was assumed.

- in the area of the planned mine, a working vertical stress of $17.9 \mathrm{MPa}$ was obtained, which corresponds to the depth of approximately $715 \mathrm{~m}$.

- the constitutive model of the elastic-ideal plastic body with Mohr-Coulomb failure condition was assumed for the rock mass.

- $\quad$ the support was projected by means of beam type elements. Between the support and rock mass, the so-called interfaces were assumed to project the lining. The parameters adopted for calculations were consistent with the parameters of tight lining. On interfaces, additional separations and slips could occur in the conditions of underground roadways. 
Table 2 Assumed strength and strain parameters in the numerical modeling.

\begin{tabular}{|c|c|c|c|c|c|c|c|c|}
\hline & Material & Bulk density & Internal friction & Cohesion & Young's & Poisson's & Compression & Tensile strength \\
\hline & & $\rho$ & $\varphi$ & $c$ & $E$ & $v$ & $R_{c}$ & $R_{r}$ \\
\hline & & $\mathrm{kg} / \mathrm{m}^{3}$ & degrees & $\mathrm{MPa}$ & $\mathrm{GPa}$ & - & $\mathrm{MPa}$ & $\mathrm{MPa}$ \\
\hline & Siltstone & 2650 & 26 & 6.8 & 11 & 0.25 & 21.7 & 2.0 \\
\hline 8 & Sandstone & 2500 & 27 & 8.5 & 14.0 & 0.25 & 27.7 & 2.7 \\
\hline & Mudstone & 2600 & 26 & 6.0 & 10.0 & 0.25 & 19.2 & 1.9 \\
\hline & Coal seam 510 & 1300 & 24 & 3.2 & 3.5 & 0.30 & 10.0 & 1.0 \\
\hline ẗ & Mudstone & 2600 & 25 & 4.3 & 8.0 & 0.25 & 12.8 & 1.3 \\
\hline $\bar{I}$ & Siltstone & 2650 & 26 & 7.0 & 11.1 & 0.25 & 22.7 & 2.2 \\
\hline
\end{tabular}

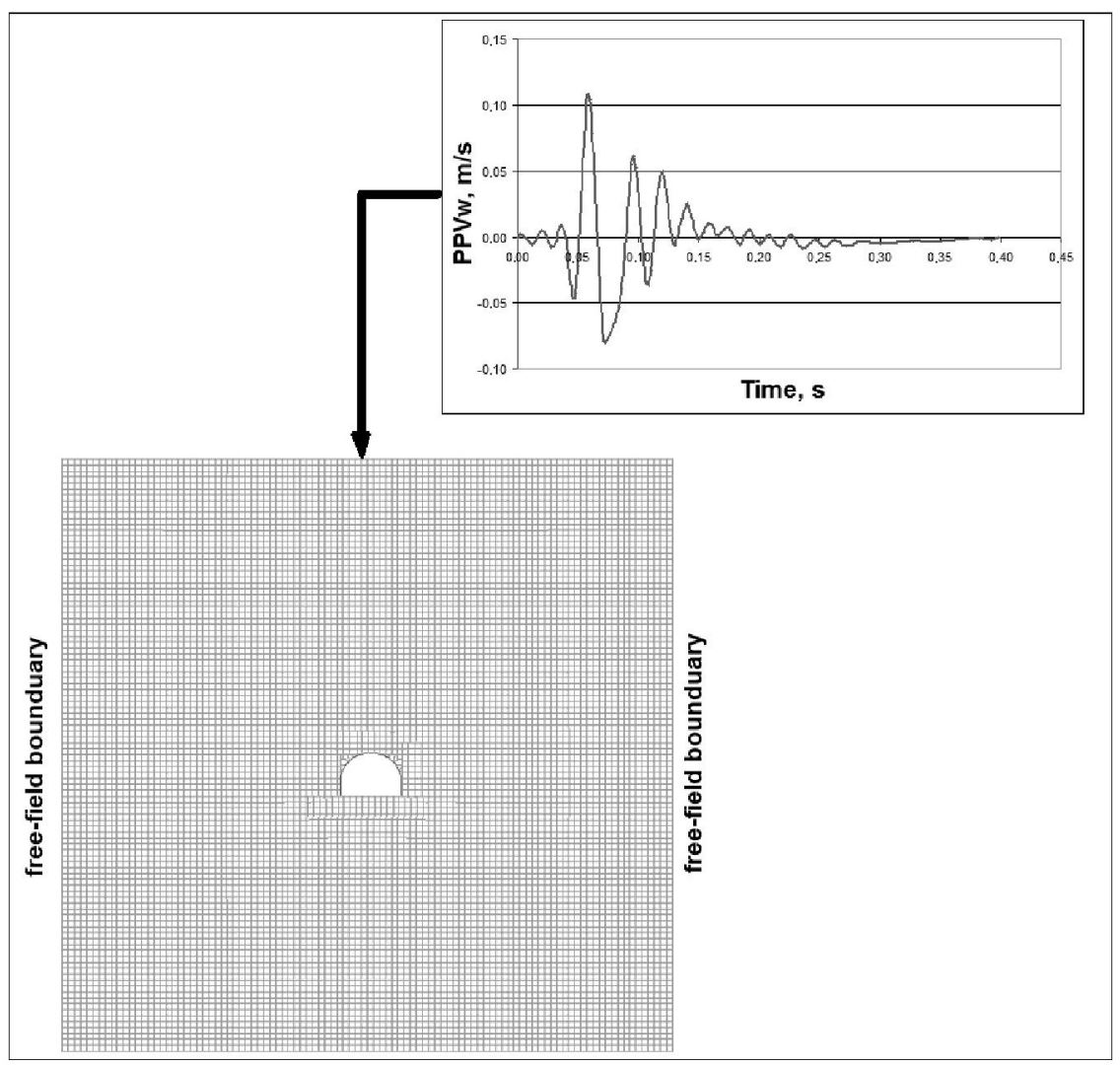

Fig. 12 Model of the rock mass and the mine working assumed for dynamic analysis.

After calculating the static phase, calculations considering additional load resulting from rock mass tremors occurrence were made. In the numerical model, certain changes were made applying the prepared source impulse on the top of the model in a form of transverse and longitudinal waves and introducing elements simulating an infinite area (freefield boundaries) on both side walls, as shown in Figure 12. Dynamic impulse was modeled as similar shape and frequency characteristic presented in Figure 10, but after weighting. As a result of such an assumption, waves propagating downward the model were not deformed under influence of the model boundaries, as conditions similar to the ones in an infinite model provided (FLAC v.6.0, 2008). In addition, $7 \%$ Rayleigh damping for a frequency of $30 \mathrm{~Hz}$ was applied in the model and based on observations of the behavior of the model.

The basic assumption was to obtain the identical weighted value of the $\mathrm{PPV}_{\mathrm{W}}$ immediately over the working (see Table 2), where geophone probes are mounted, both in the model and in situ. The value $\mathrm{PPV}_{\mathrm{w}}=0.110 \mathrm{~m} / \mathrm{s}$ (in situ measurement) was analyzed; the value was also increased to the values of 
$\mathrm{PPV}_{\mathrm{w}}=0.25,0.50,0.75$ and $1.0 \mathrm{~m} / \mathrm{s}$ for further analysis.

At the first stage, numerical calculations finished after $1 \mathrm{~s}$, i.e., when the simulated wave went through the analyzed mine working. At the second stage, the calculations finished when the maximum amplitude of the wave reached the working i.e., when the load on an analyzed roof support was the greatest.

Figure 13 presents the results of numerical calculations in the form of the maximum values of

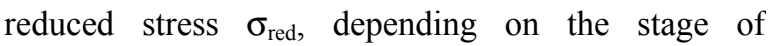
calculations.

As can be observed in Figure 13, a rock mass tremor in each case caused a specific increase in reduced stress in the profile of an arch support. Maximum increase for PPV $=1.0 \mathrm{~m} / \mathrm{s}$ was nearly $25 \%$ comparing with the static phase. When the values of $P P V_{W}$ were just one fourth $(0.25 \mathrm{~m} / \mathrm{s})$, the increase in reduced stress was approximately $5 \%$ compared with the static phase, while for the $\mathrm{PPV}_{\mathrm{W}}=0.11 \mathrm{~m} / \mathrm{s}$ the increase in reduced stress reached $2.5 \%$.

As we can see, relatively low values of $P P V_{W}$ $(<0.25 \mathrm{~m} / \mathrm{s})$ ought not to have any influence on the stability of mine workings located in the analyzed area. Only in an extreme situation i.e., when there was a significant load from the rock mass and mining remnants the influence could be more important.

To determine the permanent load on a support from the very beginning, it would be necessary to mount the presented measuring system (Figure 6) at the longwall panel face. Such monitoring would also require making a decision about the application of additional reinforcement if the applied arch support was on the limit of its load bearing capacity. Supplementing such measurements with numerical modeling would further widen the prospects and horizon of analyses to the current design of mining. The hard coal mines in Poland that are struggling with seismic hazard are obliged to have a seismic hazard intensity forecast.

\section{CONCLUSIONS}

The verification of the criterion of stability of mining openings under seismic load, elaborated for rock bursts (events causing some damage to the excavations) that occurred in 1988-2006 in the USCB (Mutke, 2007 and 2008), was performed for rock bursts phenomena that occurred in Polish Coal Company mines from 2003 till 2012 (Fig. 4). The study confirmed that rock bursts occurred when $\mathrm{PPV}_{\mathrm{W}}$ reached values within the range of 0.05 and $1.00 \mathrm{~m} / \mathrm{s}$. It has been observed that when mining activities were conducted in areas of concentrated stress, damage to the workings and support occurred at lower values of $P P V_{W}$, i.e. within the range of 0.05 and $0.2 \mathrm{~m} / \mathrm{s}$.

In this article, the results of rock mass vibrations directly affecting the roof support and the vertical load under the arch support foot, continuously measured for 78 days in the excavations, were presented. At that time 395 seismic events within the seismic energy range of 1E2 $\mathrm{J}$ and 3E5 $\mathrm{J}$ (local magnitude range of 0.1 and 2.0) were recorded. This study showed the highest value of PPV, resulted from the seismic event of energy $\mathrm{E}=3 \mathrm{E} 5 \mathrm{~J}\left(\mathrm{M}_{\mathrm{L}}=2\right)$ and hypocentral distance of $132 \mathrm{~m}$ reaching a value of $0.170 \mathrm{~m} / \mathrm{s}$ at the dominant frequency $30 \mathrm{~Hz}$. The value was $0.110 \mathrm{~m} / \mathrm{s}$ after applying a weighting function. During the seismic event, an increase in vertical load of $82.0 \mathrm{kN}$ under arch support was recorded. This result shows that even a relatively low value of $\mathrm{PPV}_{\mathrm{W}}=0.11 \mathrm{~m} / \mathrm{s}$ may result in an additional increase in vertical load under arch support. This seismic event is characterized by lower frequencies than the frequencies for explosives vibration; this is one of the main reasons that dynamic loads of roof supports in the case of strong mining seismic events are significantly higher than the dynamic loads induced by explosives vibrations at the same level of PPV.

Applying data on geological and mining conditions in the area of the measurements and the record of the tremor on 5 November 2013 and seismic energy $\mathrm{E}=3 \mathrm{E} 5 \mathrm{~J}$, numerical calculations were conducted using FLAC software. Maximum value $\mathrm{PPV}_{\mathrm{w}}=0.110 \mathrm{~m} / \mathrm{s}$ (in situ measurement) was analyzed; in addition, increased values of $\mathrm{PPV}_{\mathrm{w}}=$ $0.250,0.500,0.750$ and $1.0 \mathrm{~m} / \mathrm{s}$ were analyzed too. The vibrations in each case caused a specific increase in reduced stress in the profile of an arch support. Maximum increase for $\mathrm{PPV}_{\mathrm{W}}=1.0 \mathrm{~m} / \mathrm{s}$ was nearly $25 \%$ compared with the static phase.

From the numerical modeling results, we can conclude that relatively low values of $\mathrm{PPV}_{\mathrm{w}}<$ $0.250 \mathrm{~m} / \mathrm{s}$ ought not to have any influence on the stability of an arch steel support located in the analyzed area. In a future study, numerical modeling should be performed for the cases with significant stress concentration zone.

\section{ACKNOWLEDGMENTS}

This paper was partly developed under the $I^{2} \mathrm{M}$ project: "Innovative Technologies and Concepts for the Intelligent Deep Mine of the Future".

\section{REFERENCES}

Ansell, A.: 2004, In situ testing of young shotcrete subjected to vibrations from blasting. Tunnelling and Underground Space Technology, 19, 587-596. DOI: $10.1016 /$ j.tust.2004.01.059

Bukowska, M.: 2005, Indicative methods for assessment of liability of rocks and rock mass to rock-bumps. Research Reports of GIG - Mining and Environment, No. 866, 94-107, (in Polish).

Butler, A.G. and van Aswegen, G.: 1993, Ground velocity relationships based on a large sample of underground measurements in two South African mining regions. $3^{\text {rd }}$ International Symp. on Rockburst and Seismicity in Mines, Kingston, Ontario, Canada, Proceedings, AA Balkema, Rotterdam, 41-49. 
Dowding, Ch.H.: 1985, Blast vibration monitoring and control. Northwestern University - Library of Congress Cataloging in Publication Data, 297.

Dubiński, J. and Wierzchowska, Z.: 1973, Methods for calculation of seismic energy of mine tremors in Upper Silesia. Research Reports of GIG, No. 591, (in Polish).

Dubiński, J. and Mutke, G.: 1996, Characteristics of mining tremors within the near wave field zone. PAGEOPH, 147, No. 2, 251-261.

Dubiński, J. and Mutke, G.: 2012, Application of PPV method for the assessment of stability hazard of underground excavations subjected to rock mass tremors. AGH Journal of Mining and Geoengineering. Quarterly of AGH University of Science and Technology, 36, No.1, 125-132.

FLAC v.6.0: 2008, Dynamic Analysis. Itasca Consulting Group, Minneapolis, USA.

Hadjigeorgiou, J. and Potvin, Y.: 2008, Overview of dynamic testing of ground support. Proceedings of $4^{\text {th }}$ International Seminar on Deep and High Stress Mining, Y. Potvin (ed), Australian Centre for Geomechanics, Perth, Australia, 349-371.

Hagan, T.O. et al.: 2001, Simulated rockburst experiment an overview. The Journal of The South African Institute of Mining and Metallurgy, August, 217-222.

Heal, D.: 2010, Observation and analysis of incidences of rockburst damage in underground mines. $\mathrm{PhD}$ Thesis, University of Western Australia, School of Civil and Resource Engineering.

Jarufe, J.A. and Vasquez, P.: 2014, Numerical modelling of rock-burst loading for use in rock support design at Codelco's New Mine Level Project. Mining Technology, 123, 120-127. DOI: $10.1179 / 1743286313$ Y.0000000050

John, C.M. and Zahrah, T.F.: 1985, A seismic design of underground structures, prepared under National Science Foundation, Agbabian Associates, El Segundo, California. Report No. R-8411.

Kaiser, P.K. and Cai, M.: 2013, Rockburst damage mechanism and support design principles. Keynote Lecture in Proceeding of the 8-th International Symposium on Roburst and Seismicity in Mines RaSiM 8 (eds. Alexey and Dmitriy Malovichko). Geophysical Survey of Russian Acad. Sc. and Mining Institute of Ural Branch of Russian Acad. Sc., 349370 .

Kaiser, P.K., Vasak, P. and Suorineni, F.T.: 2005, New dimensions in seismic data interpretation with 3-D virtual reality visualisation for burst-prone mines. In Sixth International Symposium on Rockburst and Seismicity in Mines Proceedings. Controlling Seismic Risk. Potvin, Y. and Hudyma, M. (Eds). Australian Centre for Geomechanics, 33-45.

Kanamori, H., Mori, J., Hauksson, E., Heaton, T. H., Huttn, L.K. and Jones, L.M.: 1993, Determination of earthquake energy release and $\mathrm{M}_{\mathrm{L}}$ using Terrascope. Bulletin of the Seismological Society of America, 83, No. 2, 330-346.

Kidybiński, A.: 1986, Design criteria for roadway support to resist dynamic loads. International Journal of Mining and Geological Engineering, 4, 91-109.

DOI: 10.1007/BF01560669

Leonhardt, J.: 1985, Erkennen gebirgsschlaggefährdeter Bereiche aufgrund lagerstättenkundlicher Gegebenheiten. Glückauf, 121, 1069-1075.
McGarr, A., Green, R.W.E. and Spottiswoode, S.M.:1991, Strong ground motion of mine tremors: some implications for near-source ground motion parameters. Bulletin of the Seismological Society of America, 71, No. 1, 295-319.

Malmgren, L. and Nordlund, E.: 2006, Behaviour of shotcrete supported rock wedges subjected to blastinduced vibrations. International Journal of Rock Mechanics \& Mining Sciences, 43, 593-615.

DOI: $10.1016 / j . \mathrm{ijrmms.2005.11.007}$

Masny, W.: 2006, Practical application of the sensors for measuring of static and dynamic loadings. XXIX Winter School of Rock Mechanics and Geoengineering. Krynica 12-17 March, 237-245, (in Polish).

Masny, W. and Prusek, S.: 2012, The underground tests of peak particle velocities (PPV) and loads of mixed support. In: The safety of mixed support under the dynamic load conditions, Ed. M. Turek, GIG Katowice, 86-100, (in Polish).

Mutke, G.: 2002, Ground motion associated with coal mine tremors close to the underground openings. In Seismogenic Process Monitoring, Eds. H. Ogasawara, T. Yanagidani and M. Ando, A.A. Balkema Publishers, 91-102.

Mutke, G.: 2007, Characteristics of near-field ground motion resulting from mining tremors to assessing of rock bursts hazard. GIG's Scientific Works, No. 87, (in Polish).

Mutke, G.: 2008, Stability of the underground mine workings in the near-field zone of seismic events. In 21st World Mining Congress 2008 - New Challenges and Vision for Mining. Underground Mine Environment, 7-12 September 2008, Poland, Cracow. University of Scince and Technology, 89-97.

Patyńska, R.: 2014, Rock burst hazard. In: Yearly report (2013) on the natural and technical hazards in hard coal mining, Ed. J. Kabiesz. Główny Instytut Górnictwa, Katowice, 93-102, (in Polish).

PN-H-84042-1:2009, Microalloyed Steels For Shapes and Accessories Used in Mining Industry. (Polish standard).

PN-H-93441-1:2004, Hot Rolled Steel Sections for Mining Industry - Part 1: General Requirements and Tests. (Polish standard).

Reddy, N. and Spottiswoode, S.M.: 2001, The influence of geology on a simulated rockburst. The Journal of the South African Institute of Mining and Metallurgy, 101(5), 267-274.

Stjern, G. and Myrvang, A.: 1998, The influence of blasting on grouted rockbolts. Tunneling and Underground Space Technology, 13, No. 1, 65-70. DOI: 10.1016/S0886-7798(98)00021-2

Szweda, S.: 2003, Dynamic action of rock mass on the powered support legs. Journal of Mining Science, 39, No. 2, 154-161.

DOI: 10.1023/B:JOMI.0000008461.78355.1d

Stec, K.: 2014, Seismic hazard. In: Yearly report (2013) on the natural and technical hazards in hard coal mining, Ed. J. Kabiesz. Główny Instytut Górnictwa, Katowice, 81-92.

Tannant, D.D, Kaiser, P.K. and McDowell, G.M.: 1992, Dynamic support monitoring. In: Rock Support in Mining and Underground Construction, P.K. Kaiser and G.M. McCreath (eds), Balkema, Rotterdam, 657664. 


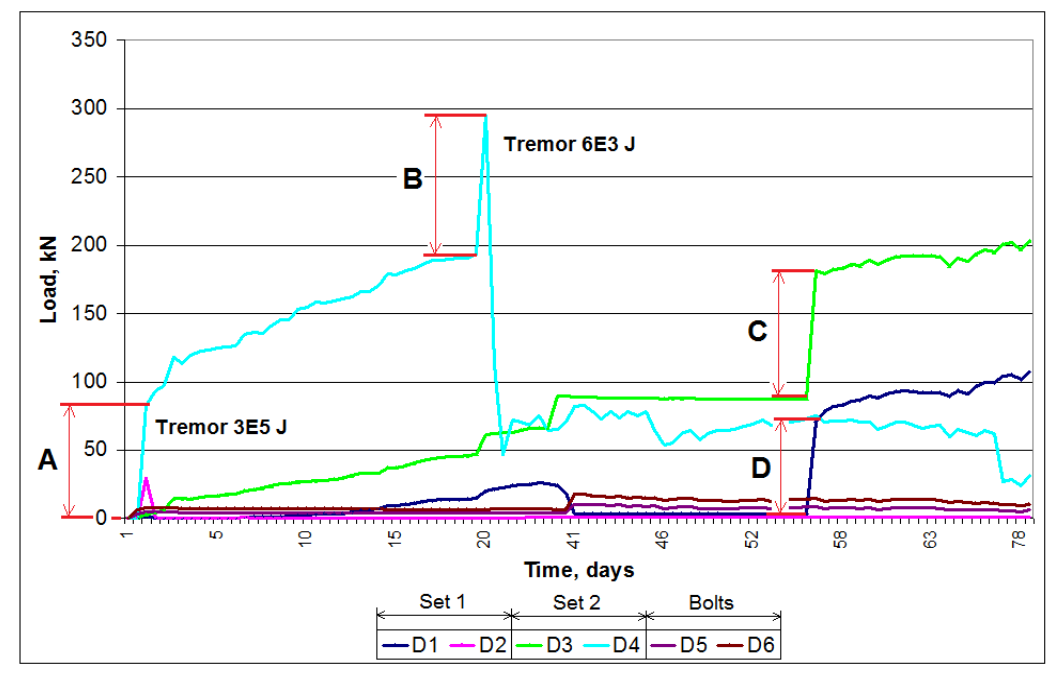

Fig. 9 Changes in the load exerted on steel arches D1 $\div$ D4 and on rock bolts D5-D6: A - load increase due to a mining tremor energy of $3 \mathrm{E} 5 \mathrm{~J}$; B - load increase due to a mining tremor energy of $6 \mathrm{E} 3 \mathrm{~J}$; C, D - load increase due to front abutment pressure.

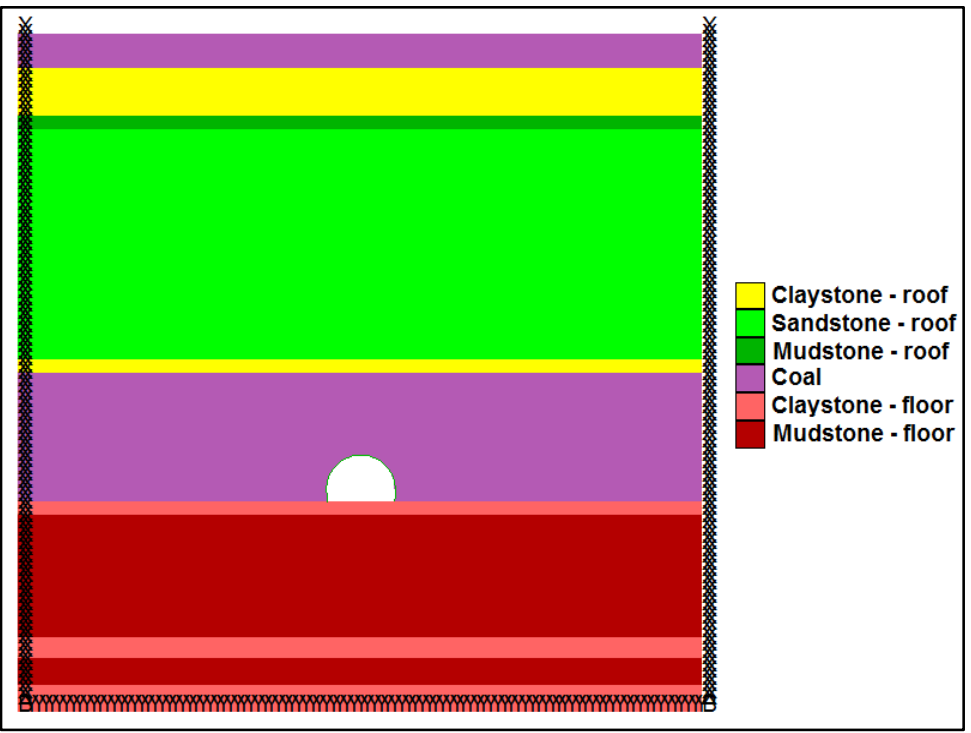

Fig. 11 Rock mass and roadway model.

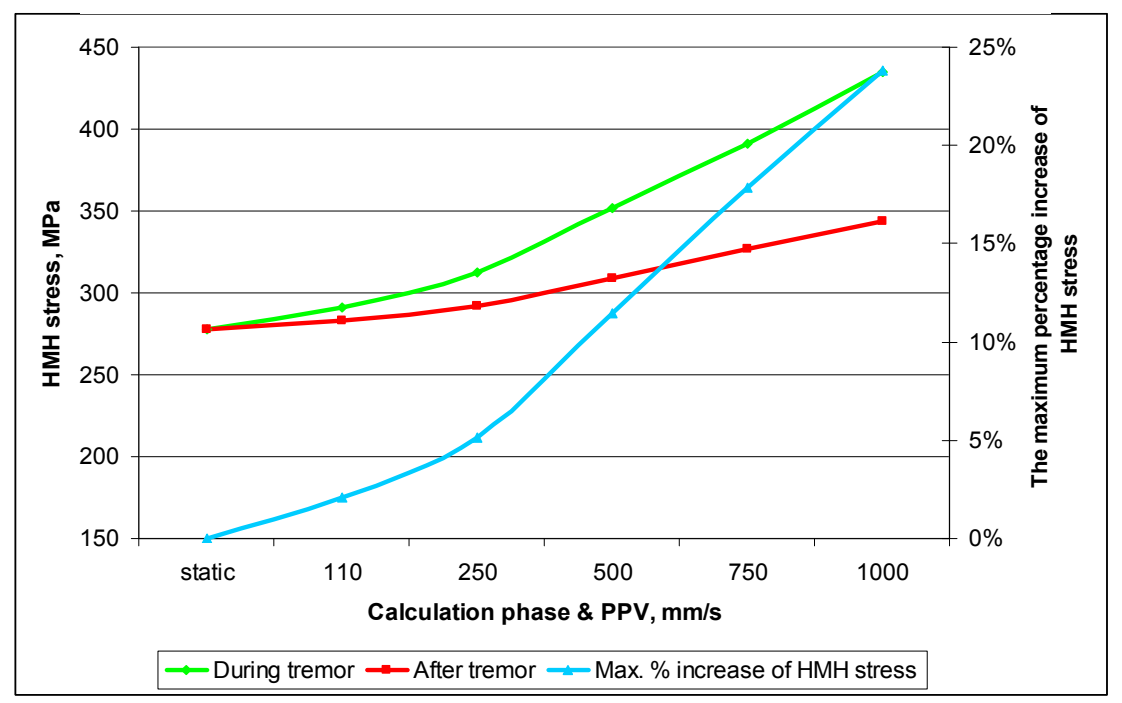

Fig. 13 Changes in the reduced stress in the arch support profile depending on the values of $\mathrm{PPV}_{\mathrm{W}}$. 